\title{
Reexamining the Conceptualization of Mistreatments and Abuses in the Workplace: Psychological Violence Story
}

\author{
Malineo Agnes Matsela \\ National University of Lesotho, P.O. Roma, Lesotho
}

\begin{abstract}
This paper examines the reconceptualization of workplace abuses into a unifying concept of psychological violence in the workplace. It argues that there is need to understand and encompass all other key concepts that address the same issue. It further argues that psychological violence is a complex phenomenon that includes varied abusive behaviours in organizations ranging from harassment to different forms of abuse that cause harm on the whole person of an employee. There is a wide range of views regarding what psychological violence with different researchers using different labels for the same phenomenon. The paper proposes reconceptualization of work related abuse to be encapsulated in the one defined concept, namely psychological violence which brings together all these otherwise diverse concepts.
\end{abstract}

Keywords: violence, psychological violence, workplace abuses, employees, workplace mistreatments

\section{Introduction}

Mistreatment and abuses in the workplace are detrimental to the success of organisations. Thus, the experiences of employees whether good or bad determine the output in organizations. However, this important element is often overlooked. Organizations operate and measure their success in terms of their financial gain. Therefore, it becomes important to reexamine the concepts which describe abuses and mistreatments that occur in the workplace because this can lead to financial loss as a result of absenteesism, high staff turnover etc.. On the basis of this, then, psychological violence becomes a more unifying concept for these wide-ranging concepts.

\section{The Framework of Psychological Violence}

In the research literature, there is a wide range of views regarding the appropriate term to use for abuses that occur in the workplace. This has resulted in what psychological violence entails with different researchers using different labels to describe the same phenomenon (Vartia-Vaananen, 2003, p. 8; Omari, 2003, p. 9). For instance in Scandinavia, the term victimization is used to describe the abusive experiences in the workplace, while in Germany, Italy, Australia, and France, mobbing or psychological violence is used interchangeably. In the USA, the concepts workplace harassment, workplace mistreatment, and emotional abuse are used (Sprattlen, 1995; Keashly, 2001). In South Africa, the concepts, bullying, mobbing and psychological violence are used (Timo et al., 2004; Steinmann, 2003). Other concepts include psychological terrorisation (Leymann, 1990), workplace trauma and employee abuse (Wilson, 1991), workplace aggression (Geffner, Geffner, Braverman,

Malineo Agnes Matsela, Ph.D., Faculty of Education, National University of Lesotho. 
Galasso, \& Marsh, 2004, p. 126; Neuman \& Baron, 2005), victimization (Smith, Singer, Hoel, \& Cooper, 2003; Aquino \& Bradfield, 2000) and finally psychological harassment by Poilpot-Rocaboy (2006). In reviewing these concepts, it becomes apparent that they all seem to constitute psychological violence.

\section{Features of Psychological Violence in the Workplace}

Various studies have identified the basic features of psychological violence which provide a framework for understanding how psychological violence occurs. The following features have been identified:

\section{Negative Acts}

This is a central feature of workplace psychological violence behaviours. It involves personal derogation through humiliation and personal criticism. They may also include physical aggression. They show in covert tactics against the target, social isolation where an individual is treated differently, undermining of professional status, tempering with tools that people need to do their job, being intimidated, micro management of one's work duties and more personal attacks on one's credibility as a person and as a professional. It further includes withholding information that a person needs to perform his/her duties. These kinds of acts can render an employee ineffective more so when coupled with removing one's responsibilities which can further make employees redundant and unwanted in their job (Hoel \& Cooper, as cited in Tehrani, 2001, p. 4; Einarsen, Hoel, Zapf, \& Cooper, 2003, p. 9; Rayner \& Keashly, as cited in Fox \& Spector, 2005, pp. 273-277).

\section{Persistence}

This is another feature that has been recognized as characteristic of psychological violence, thus, psychological violence behaviours are repeated and they persist over a period of time (Hoel \& Cooper, as cited in Tehrani, 2001, p. 4; Einarsen, Hoel, Zapf, \& Cooper, 2003, p. 9; Rayner \& Keashly, as cited in Fox \& Spector, 2005, pp. 273-277).

Hence, some researchers argue that psychological violence is not a once-off incident between co-workers, but persistence is appropriate conceptually because it helps to distinguish simple misunderstandings between co-workers and negative relationships with psychological violence featuring under the latter. Logically, psychological violence is highly interpersonal in nature, hence it cannot happen between strangers (Graves, 2002, p. 6).

\section{Long-term Duration}

Although organizational intervention may cut the psychological violence period or the victim may decide to leave the organization, long-term duration is nevertheless one of the prominent features of this phenomenon.

\section{Power Imbalance}

Power imbalance between the perpetrator and the victim results in power games where perpetrators use their power over their victims in order to undermine them for their own ends. This is the case despite the fact that psychological violence can take many forms, for example, manager against employee, employee against manager, peer against peer, and customer against employee. This is because power can either be formal or informal. Thus, formal power can be drawn from one's hierarchical position within an organization, such as in a manager to employee psychological violence. Informal power on the other hand can originate from personal contacts, organizational standing, experience and knowledge of the victim's vulnerabilities (Rayner \& Keashly, 2005 , p. 277). This therefore explains why in some cases the subordinates can still abuse their managers or superiors. 
As indicated, power imbalance between the perpetrators and the victims plays a very significant role in terms of continuous abusive behaviours. This is related to the victim's inability to defend himself/herself against unpleasant behaviours. As alluded to earlier, a minor, non-persistent misunderstanding between people who have equal power demonstrated by having access to similar resources will, according to Einarsen et al. (2003, p. 15) pass off as ordinary conflict.

\section{Subjective Perceptions}

These are subjective perceptions that targets have about the negative behaviours that are leveled against them and the meaning they attach to such experiences. Rayner et al. (2002, p. 12) and Rayner and Keashly (2005, p. 275) further make reference to labeling workplace psychological violence as such. They argue that it is questionable whether it should be used as a criterion for defining workplace psychological violence. This is because of lack of awareness of psychological violence as a phenomenon by the targets and other contributing factors such as organizational culture which are likely to make labeling certain behaviours as psychological violence difficult. Rayner et al. (2002, p. 276) and Einarsen et al. (2003, pp. 11-12) name this same feature subjective vs. objective psychological violence. They identify this as a definitional core of workplace psychological violence since it depends on the victim's subjective perception. Two important issues that arise are whether it is observable and whether it is objective. Some acts are not observable, so it becomes evident that workplace psychological violence is a subjective reconstruction and therefore, according to them psychological violence would be somewhat difficult to prove. However, this argument would not necessarily hold because the impact, experience and effect of any unwanted particular behaviour are felt by the victim and understood from his/her own perspective (Einarsen et al., 2003, p. 9).

\section{Intentionality}

This refers to deliberate effort and intention by the perpetrator to abuse the victim. There is some debate regarding intentionality as one of the core features or descriptors of psychological violence. Intentionality is mostly acknowledged by authors who are pro-aggression theories. According to them, without intentionality then no behaviour can be positively identified as psychological violence. However, intentionality is not easy to either verify or even falsify and yet it cannot be ruled out due to the systematic nature of unpleasant acts meted out to individual employees (Hoel \& Cooper, as cited in Tehrani, 2001, p. 5; Einarsen et al., 2003, p. 12; Rayner \& Keashly, 2005, p. 279; Tehrani, 2004b, p. 4).

Other researchers have also identified other features of psychological violence, for instance and Keashly and Harvey as cited in (Fox \& Spector, 2005, p. 204) reviewed literature on psychological violence and they proposed seven features or dimensions of psychological violence which are inherent in the features described in the foregoing section. These are verbal or nonverbal defining, repetitive and patterned, unwelcome and unsolicited violations of standards of appropriate conduct towards others, harmful or causing psychological or physical injury to the target, intended to harm or controllable by the actor and acts of commission and omission (Graves, 2002, p. 9).

The following concepts have been used to explain abuses that occur in the workplace and they centre around the same feautures.

\section{Harassment}

Brodsky (as cited in Einarsen et al., 2003, p. 33) describes harassment as repeated and persistent attempts by one person to torment, wear down, frustrate or get a reaction from another. It is a persistent negative 
treatment which pressurizes intimidates or otherwise discomforts. It is also described as any kind of unwanted behavior which may range from mildly unpleasant remarks to physical violence. It is further defined as an improper conduct directed at someone that a reasonable person finds unwelcome, offensive and harmful. Harassment can come from a colleague, a supervisor, a subordinate, another person in the workplace or a member of the public.

\section{Workplace Deviance}

Robinson and Bennet (as cited in Einarsen et al., 2003, p. 33) describe workplace deviance as voluntary behaviour that violates significant organizational norms and in so doing, threatens and risks the well-being of the organization or its members, or both.

\section{Workplace Aggression}

It is described by Baron and Neuman (1996) and Neuman and Baron (as cited in Fox \& Spector, 2005, p. 16) as the efforts by individuals to harm others with whom they work, or have worked or the organizations in which they are currently or previously employed. This harm is done intentionally and includes psychological and physical injury.

The defining features of aggression are firstly that, it involves intentional behaviour. Secondly, the nature of this intentional behaviour is to harm one or more people. Thirdly, it involves both direct and indirect harming actions and finally victims of aggression are motivated to avoid such behaviours meaning that such behaviours are not invited by the victims (Robertson, 1993, p. 27).

According to Baron (as cited in Fox \& Spector, 2005, p. 17) and Robertson (1993), there are various key elements or dichotomies of aggression and these are described as follows:

(1) physical-verbal;

(2) active-passive;

(3) direct-indirect.

A physical dimension involves physical actions such as assault. It also involves unwanted touching or defacement of property. Verbal dimension causes harm and pain through words such as yelling at someone and shouting at them. It also involves unfair criticism leveled against the targeted individuals, as well as damaging gossip.

Indirect aggression is observed in situations where an actor inflicts harm on something or someone that the victim values or cares about. Direct aggression on the contrary is seen through a direct harm on the victim.

Workplace aggression can be summarized as any form of behaviour directed by one or more people in a workplace with the intention of harming one or more people in the workplace in ways the intended target is motivated to avoid. The outlined features of aggression given in the foregoing paragraphs do apply to workplace aggression as well (Fox \& Spector, 2005, p. 18).

\section{Generalized Workplace Abuse}

It is defined as violations of worker's physical, psychological and/or professional integrities. It is nonsexual, psychologically demeaning or discriminatory relationships in the workplace (Richman et al., as cited in Einarsen et al., 2003, p. 33).

\section{Workplace Incivility}

This is low intensity deviant behaviour with ambiguous intention to harm the targeted individual, which 
violates the workplace norms for mutual respect. Uncivil behaviours are characterized by rudeness and lack of courtesy instead displaying a lack of regard for other people (Andersson \& Pearson, as cited in Einarsen et al., 2003, p. 33).

\section{Abusive Supervision}

This is the situation in which supervisors display hostile verbal and non-verbal behaviours (excluding physical contact) towards their subordinates (Tepper, 2000, p. 178).

\section{Ethnic Harassment}

This is a threatening verbal conduct or exclusionary behaviour that has an ethnic component and is directed at a target because of his or her ethnicity. These are behaviours that may be encountered on a daily basis and may contribute to a hostile environment, particularly for ethnic minorities (Schneider et al., as cited in Einarsen et al., 2003, p. 33).

\section{Emotional Abuse at Work}

This refers to interactions between organizational members that are characterized by repeated hostile nonverbal, often nonphysical behaviours directed at a person(s), such that the target's sense of himself/herself is negatively affected (Keashly, 2001, p. 232).

\section{Mobbing}

According to Di Martino, Hoel, and Cooper (2003) and Sheehan, Barker, and Mccarthy (2004), mobbing is a mistreatment of one person or a group of people by a group of people in the organization. Nevertheless in such circumstances, there is a ring leader who will incite others to engage in an adversarial interaction with the target.

\section{Intimidation}

It involves the use of violence or threats to force the person to do something they are not legally obliged to do or to prevent someone from doing what he has a right to do. Examples include, persistently following a person, depriving him/her of objects he/she uses and watching his/her home or workplace (Di Martino et al., 2003).

\section{Victimization}

Victimization as a concept that describes people's unpleasant experiences in the workplace has been identified in the research literature (Aquino \& Bradfield, 2000, p. 525).

Victimization is defined as the individual's self-perception of having been exposed to aggressive acts that emanate from one or more people in the workplace (Aquino \& Bradfield, 2000, p. 526).

\section{Conclusion}

The experiences and behaviours that fall within the description of each one of the defined concepts can be viewed as psychological violence. This is because an observation has been made from the research literature that studies that measure the same behaviours and experiences have been labelled with different concepts. While these concepts are varied in their meanings, the central core that binds all of them is systematic psychologically, damaging mistreatments of individuals by others in their workplace. When this continued, it may cause relentless social-psychological and psychosomatic problems to the victim. 


\section{References}

Aquino, K., \& Bradfield, M. (2000). Perceived victimization in the workplace: The role of situational factors and victim characteristics. Organization Science, 11(5), 525-537.

Di Martino, V., Hoel, H., \& Cooper, C. L. (2003). Preventing violence and harassment in the workplace. Luxembourg: Office for Official Publications of the European Committee. Retrieved July 20, 2013, from http://www.Eurofound.europa/publications/2002/112/ en/ef02112 en pdf

Einarsen, S., Hoel, H., Zapf, D., \& Cooper, C. L. (2003). Bullying and emotional abuse in the workplace: International perspectives (p. 420). London: Taylor \& Francis.

Fox, S., \& Spector, P. E. (Eds.) (2005). Counterproductive work behavior: Investigation of actors and targets (p. 329). Washington, D.C.: American Psychological Association.

Geffner, R., Geffner, R., Braverman, M., Galasso, J., \& Marsh, J. B. S. (Eds.) (2004). Aggression in organizations: Violence, abuse, and harassment at work and in schools (p. 246). Binghamton, N.Y.: Haworth Maltreatment \& Trauma Press.

Graves, D. (2002). Fighting back: Overcoming bullying in the workplace (p. 141). London: McGraw-Hill.

Hoel, H., \& Cooper, G. (2000). Destructive conflict and bullying at work (Launch of the civil service race equality network). UMIST, November.

Kanjee, A. (2001). Cross-cultural test adaptation and translation: Psychological assessment in South Africa (pp. 86-102). Retrieved May 3, 2007, from http://www.sajip.co.za/index.php/sajip/article/ view/171/168-3k

Kaplan, H. B. (1996). Psychosocial stress: Perspectives on structure, theory, life course \& methods (p. 428). San Diego, Calif: Academic Press.

Keashly, L. (2001). Interpersonal and systematic aspects of emotional abuse at work: The target's perspective. Violence and Victims, 16(3), 233-268.

Keashly, L., \& Jagatic, K. (2003). By any other name: American perspectives on workplace bullying. In S. Einarsen, D. M. Hoel, D. Zapf, \& C. Cooper (Eds.), Bullying and emotional abuse in the workplace: International perspectives in research and practice. London: Taylor \& Francis.

Leymann, H. (1990). Mobbing and psychological terror at workplaces. Violence \& Victims, 5, 119-126.

Neuman, J. H., \& Baron, R. A. (2005). Aggression in the workplace: A social psychological perspective. In S. Fox, \& P. E. Spector (Eds.), Counterproductive work behavior: Investigation of actors and targets. Washington, D.C.: American.

Omari, M. (2003). Towards dignity \& respect: An exploration of antecedents \& consequences of bullying behavior in the workplace (Research report). Retrieved July 5, 2006, from http://www.jcipp. curtin.edu.au/local/docs/discussion/2005/1.03 _Maryam\%20Omari_\%20Bullying.pdf

Poipot-Rocaboy, G. (2006). Bullying in the workplace: A proposed model for understanding the psychological harassment process. Research \& Practice in Human Resource Management, 14(20), 1-17.

Rayner, C., Hoel, H., \& Cooper, L. C. (2002). Workplace bullying: What we know, who is to blame and what can we do? (p. 208). London: Taylor \& Francis.

Robertson, D. (1993). Violence in your workplace: How to cope (p. 95). London: Souvenir Press.

Robinson, S. L., \& Bennett, R. J. (1995). A typology of deviant workplace behaviors: A multidimensional scaling study. Academy of Management Journal, 38, 555-572.

Sheehan, M., Barker, M., \& Mccarthy, P. (2004). Analysing metaphors used by victims of workplace bullying. International Journal of Management and Decision Making, 5(1), 21-34.

Smith, P. K., Singer, M., Hoel, H., \& Cooper, C. L. (2003). Victimization in the school and the workplace: Are there links? British Journal of Psychology, 94, 175-188.

Sprattlen, L. P. (1995). Interpersonal conflict which includes mistreatment in a university workplace. Violence and Victims, 10(4), 285-297.

Steinman, S. (2003). Workplace violence the health sector. Country case study: South Africa (ILO, ICN, International joint program of workplace violence in the health sector) (p. 59). Retrieved May 30, 2006, from http://www.icn.ch/SewWorkplace/WPV_HS_SouthAfrica.pdf

Tehrani, N. (2004a). Bullying: Source of chromic PTSD. British Journal of Guidance and Counseling, 32(3), 357-366.

Tehrani, N. (2004b). Workplace trauma: Concepts assessments \& interventions (p. 277). New York: Brunner Routledge.

Tehrani, N. (Ed.). (2001). Building a culture of respect: Managing bullying at work (p. 230). London: Taylor \& Francis.

Tepper, B. J. (2000). Consequences of abusive supervision. Academy of Management Journal, 43, 178-190. 
Tepper, B. J. (2000). Consequences of abusive supervision. Academy of Management Journal, 43, 178-190.

Timo, N., Fulop, L., \& Ruthjersen, A. (2004). Crisis? What crisis? Management practices and internal violence and workplace bullying in aged care in Australia. Research and Practice in Human Resource Management, 12(2), 57-59.

Timo, N., Fulop, L., \& Ruthjersen, A. (2004). Crisis? What crisis? Management practices and internal violence and workplace bullying in aged care in Australia. Research and Practice in Human Resource Management, 12(2), 57-59

Vartia-Väänänen, M. (2003). Workplace bullying: A study on the work environment well being \& health (Doctoral dissertation, Helsinki: University of Helsinki, Finish Institute of Occupational Health).

Wilson, C. B. (1991). US businesses suffer from work trauma. Personnel Journal, 47-50. 